\title{
1. From treaty practice to the UN Watercourses Convention
}

\author{
Alistair Rieu-Clarke
}

\section{INTRODUCTION*}

In 1959, following a proposal from the Bolivian Government, the UN General Assembly discussed the legal problems relating to the utilisation of international rivers. ${ }^{1}$ A key motivation for the topic was to consider whether it was appropriate for codification at the global level. Adopting a global approach would not be an easy task. In the same year Sudan and Egypt entered into an agreement that fully allocated the waters of the Nile between themselves, and to the exclusion of all upstream Nile riparians. ${ }^{2}$ If all States sharing one international river could not enter into an agreement, then what hope was there for the General Assembly to find consensus amongst States at the global level? Conversely, could a global approach act as a catalyst for stronger cooperation amongst States within individual rivers? Before these questions could be answered there was a need to ascertain what practice already existed. What bilateral and multilateral treaties had States already committed to? Did these treaties share common rules and principles? How widespread was treaty practice relating to international watercourses? To address these questions the UN General Assembly requested the UN Secretary General to survey relevant sources on the topic, including laws and legislation of Member States, bilateral and multilateral treaties, summaries of decisions of international tribunals, and studies made by non-governmental organisations. ${ }^{3}$ It could be argued that out of all these sources, bilateral and multilateral treaties offered the most accurate reflection of what States might be willing to accept at the global level. However, the survey revealed that the treaty landscape was fragmented. ${ }^{4}$ With a view to supplementing existing watercourse treaties, ${ }^{5}$ the International Law Commission (ILC) was therefore requested by the UN General Assembly, to 'take up the study of the law of the non-navigational uses of international watercourses with a view to its

* All websites cited in this chapter were live as at 31 August 2018.

1 Preliminary Studies on the Legal Problems Relating to the Utilisation and Use of International Rivers, U.N. G.A. Res. 1401(XIV) (November 21, 1959).

2 Agreement between the Republic of the Sudan and the United Arab Republic for the Full Utilisation of the Nile Waters, November 8, 1959, 453 U.N.T.S. 51.

3 UN Secretary-General, Legal Problems Relating to the Utilisation and Use of International Rivers, U.N. Doc. A/5409 (1963).

4 Progressive Development and Codification of the Rules of International Law Relating to International Watercourses, U.N. G.A. Res. 2669 (XXV) (December 8, 1970).

5 While the terms 'treaties' and 'conventions' are often used interchangeably, for the purposes of this chapter, 'watercourse treaties' will refer to legal arrangements that States have entered into concerning specific rivers, lakes and aquifers. 


\section{Research handbook on international water law}

progressive development and codification'. ${ }^{6}$ Given the fragmented nature of bilateral and multilateral watercourse treaties, the ILC had a difficult task at hand. The magnitude of this task is reflected in the length of time it took for the ILC to adopt a final set of Draft Articles; the topic was initiated in 1974 but only completed in $1994 .^{7}$ Following negotiations by States within the UN General Assembly 6th Committee in 1996 and 1997, the Convention on the Law of the Non-navigational Uses of International Watercourses was finally adopted in $1997 .{ }^{8}$

What then, was the contribution of treaty practice to the codification and progressive development of international law in this field? Was there sufficient widespread and representative practice for the ILC to rely upon bilateral and multilateral treaties in order to shape the text of the UN Watercourses Convention? Were some parts of the Convention more influenced by treaty practice than others? Were some bilateral and multilateral treaties more influential than others? In seeking answers to these questions, this chapter will trace the evolution and reach of treaty practice relating to international rivers, lakes and aquifers and consider the extent to which that treaty practice informed the development of UN Watercourses Convention. In addition, the chapter will consider the extent to which the UN Watercourses Convention has influenced treaty practice following its adoption in 1997.

\section{THE EVOLUTION AND REACH OF WATERCOURSES TREATIES}

Treaty practice relating to watercourses goes back a long way. ${ }^{9}$ It is believed that the first ever international treaty resolved a dispute concerning a watercourse stemming from the Euphrates River between two Sumarian city-States (Lagash and Umma) in 2,500 BC. ${ }^{10}$ By 1986, an estimated 3,600 watercourse treaties were believed to be in place. ${ }^{11}$ However, the vast majority of these arrangements covered navigational issues, which reflected the key transboundary issue that States were concerned with up until

6 U.N. G.A. Res. 2669, supra note 4.

7 See 'Procedural History', Audio-visual Library of International Law, http://legal.un.org/ avl/ha/clnuiw/clnuiw.html.

8 Convention on the Law of the Non-navigational Uses of International Watercourses, New York, May 21, 1997, U.N. Doc. A/RES/51/299 (1997).

9 See generally Stephen C. McCaffrey, The Evolution of the Law of International Watercourses, 45 AUSTRIAN JOURNAL OF PUBLIC INTERNATIONAL LAW 87 (1993).

10 Arthur Nussbaum, A Concise History of the LaW of Nations (Macmillan 1954). According to Jacobsen and Adams, Lagash and Umma had fought over fertile land adjacent to Euphrates River for generations, with Lagash (downstream) unable to prevent Umma (upstream) from breaching and obstructing the waters that served the border fields (see Thorkild Jacobsen \& Robert Adams, Salt and Silt in Ancient Mesopotamian Agriculture, 128 SCIENCE 1251 (1958)).

11 Mark A. Giordano \& Aaron T. Wolf, The World's International Freshwater Agreements: Historical Developments and Future Opportunities, in UNEP, OREGON STATE UNIVERSITY AND FAO, ATLAS OF INTERNATIONAL FRESHWATER AGREEMENTS 6 (UNEP 2002). 
and during the 19th Century. ${ }^{12}$ A subset of around 400 treaties relate to nonnavigational issues. ${ }^{13}$ The earlier treaties tended to focus on single uses, such as fishing, ${ }^{14}$ joint studies $^{15}$ or hydropower. ${ }^{16}$ By the late 1970s, however, there was growing awareness of the need to take a holistic approach to water resources management. The 1978 Great Lakes Agreement between Canada and the United States, for example, had the purpose of restoring and maintaining, 'the chemical, physical, and biological integrity of the waters of the Great Lakes Basin Ecosystem'. ${ }^{17}$ Another example is the Convention creating the Niger Basin Authority, which has the aim 'to ensure an integrated development of the Niger Basin in all fields'. ${ }^{18}$

In terms of the reach of watercourse treaties, the number of agreements dealing with non-navigational uses of international watercourses (i.e., 400) would seem encouraging given that there are an estimated 275 international watercourses. ${ }^{19}$ However, a more detailed investigation shows that fragmentation remains a challenge within the context of international watercourses. More specifically, there is significant variation in the content of treaties, the States party to them, and the watercourses covered. For instance, in Africa there are 64 international watercourses, but only 19 are covered by watercourse treaties. ${ }^{20}$ Across Asia, there are 57 international watercourses, but only 24 are covered by treaty arrangements. ${ }^{21}$ In South America there are 38 international watercourses but only six are covered by treaty arrangements. ${ }^{22}$ The record is more encouraging in Europe and North America. Europe has the most extensive practice both in terms of the number of international watercourses and the reach of watercourse treaties, with most of the 69 international watercourses covered by watercourse treaties. $^{23}$ In North America, there are 19 international watercourses. Treaty practice is

12 Ariel Dinar, Shlomi Dinar, Stephen C. McCaffrey \& Deane McKinney, Bridges OVER WATER: UNDERSTANDING TRANSBOUNDARY WATER CONFLICT, NEgOTIATION AND CoOperation, 58, 58-60 (World Scientific Publishing Company 2007).

13 UNEP, OREgOn State University and FAO, ATLAS OF INTERNATIONAL Freshwater AGREEMENTS (UNEP 2002).

14 See for example, Convention Concerning Fishing in the Waters of the Danube, Bucharest, January 29, 1958, 339 U.N.T.S. 23; Preliminary Convention Between Bolivia and Peru for the Exploitation of Fisheries in Lake Titicaca, Lima, July 17, 1935.

15 See for example, Agreement Between Bolivia and Peru Concerning a Preliminary Economic Study of the Joint Utilisation of the Waters of Lake Titicaca, La Paz, February 19, 1957.

16 See for example, Agreement Between the Government of the Republic of Austria and the Government of the Federal Republic of Germany and of the Free State of Bavaria concerning the Donaukraftwerk-Jochenstein-Aktiengesellschaft (Danube Power-Plant and Jochenstein JointStoch Company), February 13, 1952.

17 Agreement Between the United States and Canada on Great Lakes Water Quality, Ottawa, November 22, 1978.

18 Convention Creating the Niger Basin Authority, Faranah, November 21, 1980; see also Agreement on the Action Plan for the Environmentally Sound Management of the Common Zambezi River System, Harare, May 28, 1987.

19 UN-Water, Shared Benefits, Shared Responsibilities (UNESCO 2008).

20 UNEP, supra note 13.

21 Id.

22 Id.

23 Id. 


\section{Research handbook on international water law}

dominated by two bilateral arrangements, the 1909 Boundary Waters Treaty, between US and Canada; and the 1944 Treaty on the Utilisation of Waters of the Colorado and Tijuana Rivers and of the Rio Grande between US and Mexico. ${ }^{24}$

A further challenge is that there appears to be a tendency for States to enter into bilateral arrangements, even when watercourses are shared by more than two States. ${ }^{25}$ As noted above, Egypt and Sudan entered into arrangements that relate to the Nile waters, which is shared by 11 countries (Tanzania, Uganda, Rwanda, Burundi, Congo, Kenya, Ethiopia, Eritrea, South Sudan, Sudan and Egypt). Finding consensus on a basin-wide agreement amongst all Nile States has proven to be challenging. ${ }^{26}$ Through the Nile Basin Initiative the Nile Basin States negotiated the text of an agreement that would apply to the entire basin. However, to date only the upstream States have endorsed the text of the so-called Nile Basin Co-operative Framework Agreement (CFA). ${ }^{27}$ A decision by seven upstream States to open the CFA for signature was opposed by Egypt and Sudan. ${ }^{28}$

The CFA is not unique in missing key basin States. While a watercourse agreement for the sustainable development of the Mekong was adopted in 1995, both China and Myanmar have not yet become party to it. ${ }^{29}$ The 1995 Mekong Agreement aims to foster cooperation:

$\ldots$ in all fields of sustainable development, utilization, management and conservation of the water and related resources of the Mekong River Basin including, but not limited to irrigation, hydro-power, navigation, flood control, fisheries, timber floating, recreation and tourism, in a manner to optimize the multiple-use and mutual benefits of all riparians and to

24 See also Great Lakes Water Quality Agreement, Washington, September 7, 2012; Great Lakes - St Lawrence River Basin Sustainable Water Resources Agreement, December 13, 2005; Treaty Relating to Cooperative Development of the Water Resources of the Columbia River Basin, Ottawa, January 17, 1961; Treaty Between Canada and the United States of America Concerning the Diversion of the Niagara River, Washington, October 10, 1950; Treaty Between Canada and the United States of America relating to the Skagit River and Ross Lake, and the Seven Mile Reservoir on the Pend d'Oreille River, Washington, April 2, 1984; Agreement between the Government of Canada and the Government of the United States of America for water supply and flood control in the Souris river basin, Regina, October 26, 1989; Convention between Canada and the United States of America providing for Emergency Regulation of the Level of Rainy Lake and the Level of other Boundary Waters in the Rainy Lake Watershed, Ottawa, September 15, 1938; Convention and Protocol between His Britannic Majesty in Respect of the Domination of Canada and the United States for Regulating the Level of the Lake of the Woods, Washington, February 24, 1925.

25 Neda Aa Zawahri \& Sara McLaughlin Mitchell, Fragmented Governance of International Rivers: Negotiating Bilateral versus Multilateral Treaties, (2011) 55(3) INTERNATIONAL STUDIES QUARTERLY 835.

26 Salman M.A. Salman, The Nile Basin Cooperative Framework Agreement: A Peacefully Unfolding African Spring (2012) 38 WATER INTERNATIONAL 17.

27 Nile Basin Initiative, Cooperative Framework Agreement, http://www.nilebasin.org/ index.php/nbi/cooperative-framework-agreement.

28 See Musa Mohammed Abseno, Nile River Basin, in THE UN WATERCOURSES CONVENTION IN FORCE - STRENGTHENING INTERNATIONAL LAW FOR TRANSBOUNDARY WATER MANAGEMENT (Flavia Rocha Loures \& Alistair Rieu-Clarke eds, Routledge 2013).

29 See Bennett Bearden, Alistair Rieu-Clarke \& Sokhem Pech, Mekong Basin, in id. 
minimize the harmful effects that might result from natural occurrences and man-made activities. $^{30}$

Not having China, the upstream State, party to the 1995 Mekong Agreement poses a critical challenge to implementing this broad aim. China has plans to build eight dams on the upstream of the Mekong River, five of which are already in operation. ${ }^{31}$ Additionally, Chinese companies continue to influence the construction and operation of hydropower projects within the other Mekong States of Laos, Cambodia, Myanmar, Thailand and Vietnam. ${ }^{32}$

Another challenge in terms of fragmentation of the treaty architecture is the varying quality of watercourse treaties. A recent survey by UNEP concluded that, 'while many transboundary agreements exist, more effort is needed to update them to reflect modern principles of transboundary water management'. ${ }^{33}$ Along similar lines, UN-Water has suggested that, 'existing agreements are sometimes not sufficiently effective to promote integrated water resources management due to ... shortcomings in the agreements themselves'. ${ }^{34}$ Several regional assessments have highlighted gaps between the provisions contained within the UN Watercourses Convention and watercourses treaties. In the Central American context, López and Sancho maintain that while formal agreements are generally lacking, where they do exist, they tend to be narrowly focused on border demarcation or the establishment of border institutions. ${ }^{35}$ Garane and AbdulKareem review existing watercourse treaties in West Africa, and conclude that 'many West African agreements are still lacking relevant principles and mechanisms to sufficiently manage and protect the watercourses'. ${ }^{36}$ In analysing watercourse treaties in Central Asia, Ziganshina points to an abundance of watercourse treaties, but suggests that as a whole they fall short of 'contemporary principles of international water law', and 'neglect the significance of establishing a sound procedural system of transboundary water cooperation'. ${ }^{37}$ Similar conclusions have been reached within the context of the Indus River Basin shared between India and Pakistan. Sarfraz, for instance,

30 Agreement on the Cooperation for the Sustainable Development of the Mekong River Basin, Chiang Rai, April 5, 1995.

31 International Centre for Environmental Management, Strategic Environmental Assessment of Hydropower on the Mekong Mainstream (MRC 2010); Pham N. Bao, Bijon K. Mitra \& T. Kuyama, Integrated Approach for Sustainable Hydropower Development in the Mekong River Basin (2017) 7(1) ENVIRONMENT AND NATURAL RESOURCES RESEARCH 60.

32 See Oliver Hensengerth, Water Governance in the Mekong Basin: Scalar Tradeoffs, Transnational Norms and Chinese Hydropower Investment, in CHINESE ENCOUNTERS IN SOUTHEAST ASIA: How PEOPLE, MONEY AND IDEAS FROM CHINA ARE CHANGING A REGION, 174-91 (Pal Nyiri \& Danielle Tan eds, University of Washington Press 2017); Philip Hirsch, The Shifting Regional Geopolitics of Mekong Dams (2016) 51 Political GeOGRAPHY 63.

33 UNEP-DHI and UNEP, Transboundary River Basins: Status and Trends (UNEP 2016), 110.

34 UN-Water, supra note 19, at 6.

35 Alexander López \& Ricardo Sancho, Central America, in The UN WaTERCOURSES CONVENTION IN FORCE - STRENGTHENING INTERNATIONAL LAW FOR TRANSBOUNDARY WATER MANAGEMENT, supra note 28.

36 Amidou Garanne \& Teslim Abdul-Kareem, West Africa, in id.

37 Dinara Ziganshina, Aral Sea Basin, in id. 
maintains that the 1960 Indus Treaty, while still relevant, could benefit from incorporating 'contemporary environmental standards', as reflected in the UN Watercourses Convention. ${ }^{38}$

However, it should also be noted that in the dispute between India and Pakistan concerning the Kishenganga Project, the Permanent Court of Arbitration, through a contemporary interpretation of the 1960 Indus Treaty, stipulated that both parties should account for the environmental flow requirements. ${ }^{39}$ The Permanent Court of Arbitration is not alone in accounting for more recent developments in environmental standards when interpreting earlier treaties. ${ }^{40}$ In the Gabčikovo-Nagymaros case, the International Court of Justice (ICJ) noted that 'newly developed norms of environmental law' should be taken into account by Hungary and Slovakia when implementing a bilateral Treaty that they entered into in 1977.41 Along similar lines, the ICJ in the Case Concerning Pulp Mills on the River Uruguay, when interpreting a 1975 bilateral treaty between Argentina and Uruguay, stipulated that the agreement:

... has to be interpreted in accordance with a practice, which in recent years has gained so much acceptance among States that it may now be considered a requirement under general international law to undertake an environmental impact assessment where there is a risk that the proposed industrial activity may have a significant adverse impact in a transboundary context, in particular, on a shared resource. ${ }^{42}$

These examples point to the important relationship between watercourse treaties and custom, as well as the relationship between global framework conventions and watercourse treaties. The next section explores these relationships in further detail.

\footnotetext{
38 Hamid Sarfraz, Revisiting the 1960 Indus Water Treaty (2013) 38(2) WATER INTERNATIONAL 20.

39 The Indus Waters Kishenganga Arbitration (Pakistan v. India), Final Award, 2013 Permanent Court of Arbitration (December 20).

40 See generally, EIRIK BJORge, The EvOlutionary InTERPRETATION OF TrEATIES (Oxford University Press 2014).

41 Gabčíkovo-Nagymaros Project (Hung. v. Slovk.), Judgment, 1997 I.C.J. Rep. 7, (Sept. 25). The ICJ went on to observe that:
}

Throughout the ages, mankind has, for economic and other reasons, constantly interfered with nature. In the past, this was often done without consideration of the effects upon the environment. Owing to new scientific insights and to a growing awareness of the risks for mankind - for present and future generations - of pursuit of such interventions at an unconsidered and unabated pace, new norms and standards have been developed, set forth in a great number of instruments during the last two decades. Such new norms have to be taken into consideration, and such new standards given proper weight, not only when States contemplate new activities but also when continuing with activities begun in the past. This need to reconcile economic development with protection of the environment is aptly expressed in the concept of sustainable development (para. 140).

42 Case Concerning Pulp Mills on the River Uruguay (Arg. v. Uru.), Judgment, 2010 I.C.J. Rep.14, II 204 (Apr. 20). 


\section{INFLUENCE OF TREATY PRACTICE ON THE DRAFTING OF UN WATERCOURSES CONVENTION}

A major challenge faced by the ILC in drafting what ultimately became the UN Watercourses Convention was how to extrapolate key rules and principles related to international watercourses from a fragmented system of watercourse treaties. Treaties were not, of course, the only source that informed the drafting of the UN Watercourses Convention. In addition to treaty practice, the ILC considered, inter alia, diplomatic correspondence and official papers; outputs of intergovernmental organisations, outcomes of meetings and conferences; reports and studies of intergovernmental and international non-governmental organisations; studies of individual experts; and decisions of international courts and tribunals. ${ }^{43}$

An area that triggered considerable discussion during the drafting of the text of the UN Watercourses Convention was the definition of a 'watercourse'. It was the opinion of some States that the Convention should be narrow in scope and only cover the main channel of a watercourse. ${ }^{44}$ Conversely, it was maintained by other States that the Convention should embrace a drainage basin approach - an 'international drainage basin' being, 'a geographical area extending over two or more States determined by the watershed limits of the system of waters, including surface and underground waters, flowing into a common terminus'. ${ }^{45}$ The latter definition was taken from the Helsinki Rules on the Uses of the Waters of International Rivers (Helsinki Rules), which were adopted by the International Law Association in 1966. While not a legally binding treaty, the Helsinki Rules had proven highly influential in the 1960 to 1980s in shaping the content of watercourse treaties, particularly across Africa. ${ }^{46}$

One of the challenges in reaching consensus on the concept of a watercourse was the significant diversity in treaty practice related to the use of terms. Some treaties focused on a specific infrastructure project ${ }^{47}$ or the carrying out of a joint study. ${ }^{48}$ Other

43 See generally, ATtila TANZi \& MAURicio ARCARi, The United NATIONS Convention ON THE LAW OF INTERNATIONAL WATERCOURSES: A FRAMEWORK FOR SHARING (Kluwer Law International 2001).

44 See generally, Alistair Rieu-Clarke, Determining Sovereign Rights and Duties over International Watercourses: The Contribution of the International Law Commission and the UN General Assembly, in A History OF WATER - SOVEREIGNTY AND INTERNATIONAL WATER LAW 149-174 (Vol. 2: IB, Terje Tvedt et al., eds., Tauris 2015).

45 See Art. II, Helsinki Rules on the Uses of the Waters of International Rivers, adopted by International Law Association, 52nd Conference, Helsinki.

46 Charles B. Bourne, The International Law Association's Contribution to International Water Resources Law, (1996) 36(2) NATURAL RESOURCES JOURNAL 155.

47 See for example, Agreement Between the Government of the Republic of Austria and the Government of the Federal Republic of Germany and of the Free State of Bavaria concerning the Donaukraftwerk-Jochenstein-Aktiengesellschaft (Danube Power-Plant and Jochenstein JointStoch Company), February 13, 1952.

48 See for example, Agreement Between Bolivia and Peru Concerning a Preliminary Economic Study of the Joint Utilisation of the Waters of Lake Titicaca, La Paz, February 19, 1957. 
agreements focused on certain uses such as fisheries, ${ }^{49}$ water allocation, ${ }^{50}$ water supply, ${ }^{51}$ monitoring, ${ }^{52}$ flood control, ${ }^{53}$ water quality and pollution, ${ }^{54}$ hydropower ${ }^{55}$ or irrigation. ${ }^{56}$ However, the ILC was able to point to some treaty practice that had embraced the notion of a watercourse being a system of surface waters and connected groundwaters. ${ }^{57}$ Such practice dated back to the Treaty of Versailles, which used the term 'river system', 58 the 1921 Danube Statute, which referred to an 'internationalised river system', ${ }^{59}$ the 1950 USSR-Hungary Treaty, which covered, 'the water systems of the Tisza river basin', ${ }^{60}$ and the 1960 Indus Water Treaty, which referenced, 'the Indus system of rivers'.61 The ILC also observed that the practice in more recent treaties appeared to embrace a holistic approach in dealing with watercourse systems in their entirety. ${ }^{62}$ This led the ILC to conclude that, 'States recognise in their practice the importance of dealing with international watercourse systems in their entirety'.63 Ultimately, this 'systems' thinking found expression in the definition of a 'watercourse' contained in the UN Watercourses Convention. Article 2 of the Convention defined a 'watercourse' as being, 'a system of surface water and groundwaters constituting by virtue of their physical relationship a unitary whole and normally flowing into a common terminus'. ${ }^{64}$ Reaching agreement on the definition of a 'watercourse' and the appropriate scope of the UN Watercourses Convention can therefore be seen as an

49 See for example, Convention Concerning Fishing in the Waters of the Danube, Bucharest, January 29, 1958; Preliminary Convention Between Bolivia and Peru for the Exploitation of Fisheries in Lake Titicaca, Lima, July 17, 1935.

50 See for example Treaty between the Government of the Republic of India and the Government of the People's Republic of Bangladesh on Sharing of the Ganga/Ganges waters at Farakka, New Delhi, December 12, 1996.

51 Agreement Between the Government of the French Republic and the Spanish Government Relating to Lake Lannoux, Madrid, July 12, 1958.

52 Agreement between Chad, Egypt, Libya and Sudan concerning the monitoring and exchange of groundwater information of the Nubian Sandstone Aquifer System, October 5, 2000.

53 See for example, Convention between the Government of the Union of Soviet Socialist Republics and the Government of the Romanian People's Republic Concerning Measures to Prevent Floods and to Regulate the Water Regime of the River Prut, December 25, 1952.

54 See for example, Convention Concerning the Protection of Italo-Swiss Waters Against Pollution, Rome, April 20, 1972.

55 See for example, Treaty Relating to Cooperative Development of the Water Resources of the Columbia River Basin, Washington, January 17, 1961.

56 Agreement Between Iran and the Soviet Union for the Joint Utilisation of the Frontier Part of the Rivers Aras and Atrak for Irrigation and Power General, Tehran, August 11, 1957.

57 Draft Articles on the Law of the Non-navigational uses of International Watercourses and Commentaries thereto, in ILC, Yearbook of the Law Commission, 1994, Vol. II (Pt 2), 90-92.

58 Treaty of Versailles, Paris, June 28, 1919.

59 Convention Instituting the Definitive Statute of the Danube, Paris, July 23, 1921.

60 Treaty between USSR and Hungary Concerning the Regime of the Soviet-Hungarian

State Frontier and Final Protocol, Moscow, February 24, 1950.

61 Indus Water Treaty, Karachi, September 19, 1960.

62 Draft Articles, supra note 57, at 91.

63 Id.

64 UN Watercourses Convention, supra note 8. 
example of where the ILC relied upon more contemporary treaty practice, backed up by non-binding instruments and scientific understanding.

Another challenge for the ILC was to find consensus amongst States on the key substantive norms that should be included within the Convention. Ultimately, the Convention is founded upon two substantive norms: equitable and reasonable utilisation, and no significant harm. ${ }^{65}$ It was not difficult for the ILC to find support for both norms within treaty practice. For instance, ILC Special Rapporteur Stephen McCaffrey observed that, '[t]the basic principles underlying the doctrine of equitable utilization have been recognized, explicitly or implicitly, in numerous international agreements between States located in all parts of the world'. ${ }^{66}$ Similarly, the ILC maintained that the requirement to take all appropriate measures to prevent significant harm could be deduced from both international watercourse treaties and various multilateral conventions. ${ }^{67}$

However, while there may have been widespread practice of States entering into treaty arrangements related to equitable and reasonable utilisation, and no significant harm, the relationship between the two norms had not been clearly articulated. Lack of agreement on the relationship between the two norms was clearly evident in the debates amongst States during the drafting and negotiation of the UN Watercourses Convention. ${ }^{68}$ Upstream States tended to favour the principle of equitable and reasonable utilisation, while downstream States preferred the principle of no significant harm. ${ }^{69}$ In the end, a compromise text was set forth that, 'aimed at avoiding significant harm as far as possible while reaching an equitable result in each concrete case'. ${ }^{70}$ States were therefore obliged to 'take all appropriate measures to prevent the causing of significant harm to other watercourse States', ${ }^{71}$ but where such harm nevertheless occurred, its lawfulness was to be determined on the basis of whether it might be deemed equitable and reasonable. ${ }^{72}$ It can be argued that the UN Watercourses Convention therefore built upon treaty practice in support of the two substantive norms of equitable and reasonable utilisation and no significant harm, but also helped to clarify their relationship.

Another significant contribution of the UN Watercourses Convention was to set out procedural rules in the cases of planned measures. These procedural rules stemmed

65 See Arts 5-7, 10 and 20-23, UN Watercourses Convention, id.

66 Stephen C. McCaffrey (Special Rapporteur), Second Report on the Law of the Nonnavigational Uses of International Watercourses, U.N. Doc A/CN.4/399 and Add.1 and 2, 103 (March 19, 1986).

67 Draft Articles, supra note 57, at 91, 103.

68 See for example, Summary Record of the First Part of the $62^{\text {nd }}$ Meeting, U.N. Doc. A/C.6/51/SR.62, 3 (August 29, 1997).

69 Patricia Wouters, An Assessment of Recent Developments in International Watercourses Law through the Prism of the Substantive Rules Governing Use Allocation, 36 NATURAL Resources Journal 417 (1996); Albert E. Utton, Which Rule Should Prevail in International Water Disputes: That of Reasonableness or that of No Harm?, 36(3) NATURAL RESOURCES JOURNAL 635 (1996).

70 Draft Articles, supra note 57, at 103.

71 Art. 7, UN Watercourses Convention, supra note 8.

72 Art. 5 and $6, i d$. 
from a more general obligation upon States to cooperate on the basis of sovereign equality, territorial integrity, mutual benefit and good faith. ${ }^{73}$ The Convention sets out detailed requirements for when States should notify other watercourse States of any planned measures, and if necessary, enter into consultations. ILC Special Rapporteur Schwebel introduced the topic of notification and consultation into the articles, through reliance, in part, on treaty practice. ${ }^{74}$ However, treaty practice, where it existed, tended to provide for general principles of notification, and only in some incidences, consultation. Examples of detailed requirements the likes of which eventually found expression in the text of the UN Watercourses Convention were few and far between..$^{75}$ While it might therefore be argued that the provisions on planned measures were founded upon a treaty practice related to notification and consultation, the Watercourses Convention adds significantly more detail concerning how these rules pertaining to notification and consultation are to be implemented.

Dispute settlement was another area that generated considerable discussion amongst the States when drafting the UN Watercourses Convention. The outcome was a detailed procedure contained within the Convention by which States could settle their disputes in a peaceful manner. Pursuant to the Convention, parties are first encouraged to settle any dispute by negotiation. ${ }^{76}$ If negotiation fails, parties may 'jointly seek the good offices of, or request mediation or conciliation by, a third party, or make use, as appropriate, of any joint watercourse institutions that may have been established by them or agree to submit the dispute to arbitration or to the International Court of Justice'. ${ }^{77}$ However, if the parties are unable to resolve the dispute by the aforementioned means the dispute can be submitted to 'impartial fact-finding' by one or both parties to the dispute. ${ }^{78}$ The Convention then sets out details of how the fact-finding commission should be established and operate. ${ }^{79}$ Ultimately, the factfinding commission is mandated to submit a report to the parties, 'setting forth its findings and the reasons therefore and such recommendations as it deems appropriate for an equitable solution of the dispute'.$^{80}$ The parties to the dispute are obliged to consider the recommendations in good faith. ${ }^{81}$

Much of the debate concerning dispute settlement provisions during the drafting of the Watercourses Convention centred on whether third-party settlement should be

73 Art. 8, id.

74 Stephen Schwebel (Special Rapporteur), Third Report on the Law of the Nonnavigational Uses of International Watercourses, U.N. Doc. A/CN.4/348, II II 156-183 (December 11, 1981); See also, Stephen C. McCaffrey (Special Rapporteur), Third Report on the Law of the Non-navigational Uses of International Watercourses, U.N. Doc. A/CN.4/406 and Add.1 and 2 (March 30, 1987).

75 One example that did prove influential in the work of the ILC was the Statute of the River Uruguay, Salto, February 26, 1975 between Uruguay and Argentina, which set out a detailed notification procedure for planned measures in Arts 7-13.

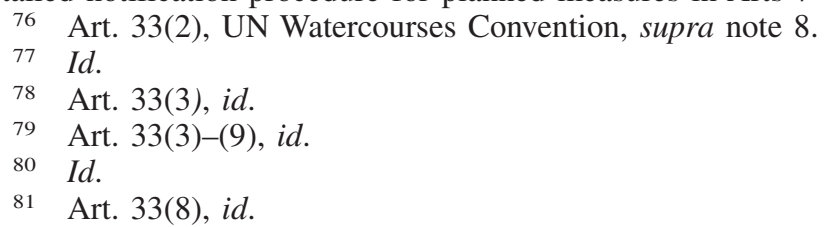


legally binding or not. Various modes of third-party intervention had been included in watercourse treaties. The 1975 Iran-Iraq Treaty, for example, required the contracting parties to 'have recourse, within a three-month period, to the good offices of a friendly third State'.82 The 1975 Iran-Iraq Treaty, then stipulates that, 'should one of the two Parties refuse to have recourse to the good offices or should the good-offices procedure fail, the dispute shall be settled by arbitration within a period of no more than one month after the date of such refusal or failure'. ${ }^{83}$ Under the 1960 Indus Treaty, any difference of a factual or technical (engineering) nature, shall be referred to a 'Neutral Expert', who should be an engineer. ${ }^{84}$ The Indus Treaty stipulates that any decision of a neutral expert is to be 'final and binding'. ${ }^{85}$ However, legal disputes relating to the Indus Treaty, and others that have not been resolved through other steps in the dispute settlement process (question, difference or dispute), may be submitted by either party to compulsory and binding arbitration. ${ }^{86}$ Similarly, the 1967 France-Italian Convention, requires that, 'any disputes relating to the interpretation and application of this Convention which cannot be settled through the diplomatic channel shall be submitted for arbitration at the request of either Party' ${ }^{87}$ Other treaties simply oblige States to submit a dispute to arbitration or adjudication after a certain period of time without stipulating whether or not such a request requires consensus. ${ }^{88} \mathrm{~A}$ further approach is for

82 Art. 6, Treaty Concerning the State Frontier and Neighbourly Relations Between Iran and Iraq, Baghdad, June 13, 1975.

83 Art. 6(4), Iran-Iraq Treaty, id.

84 Art. 9(2), Indus Water Treaty, supra note 61.

85 Annexure F, Part 2, I11, Indus Water Treaty, id; see for example, Salman M.A. Salman, Baglihar Difference and its Resolution Process - a Triumph for the Indus Waters Treaty? (2008) 10 WATER POLICY 105.

86 Id., see for example, Kishenganga Arbitration, supra note 39.

87 Art. 13, Franco-Italian Convention Concerning the Supply of Water to the Commune of Menton, Paris, September 28, 1967. See also, Art. 12(1), Agreement between Nepal and India on the Gandak Irrigation and Power Plant, Kathmandu, April 12, 1959; Art. 45, Convention Regarding the Regime of Navigation on the Danube, Belgrade, August 18, 1948; Art. 25, Agreement Between the Government of the Republic of Austria and the Government of the Federal Republic of Germany and of the Free State of Bavaria Concerning the DonaukraftwerkJochenstein-Aktiengesellschaft (Danube Power-Plant and Jochenstein Joint-Stock Company), February 13, 1952.

88 See for example Treaty on the Lesotho Highlands Water Project Between Lesotho and South Africa, Maseru, October 24, 1986; Art. 69, Treaty Between Netherlands and Germany Concerning the Course of the Common Frontier, the Boundary Waters, Real Property Situated Near the Frontier, Traffic Crossing the Frontier on Land and via Inland Waters, and Other Frontier Questions, The Hague, April 8, 1960; Art. 13, Agreement Between Italy and Switzerland on the Reno di Lei Hydraulic Concession, Rome, June 18, 1949; Art. 24, Convention Creating the Organisation for the Development of the Senegal River, Nouakchott, March 11, 1972; Art. 11, State Treaty Between the Grand Duchy of Luxembourg and the Land RhinelandPalatinate in the Federal Republic of Germany Concerning the Construction of Hydroelectric Power-Installations on the Our, Trier, July 10, 1958; Art. 22, State Treaty Between the Grand Duchy of Luxembourg and the Land Rhineland-Palatinate in the Federal Republic of Germany Concerning the Construction of a Hydro-Electric Powerplant on the Sauer (Sure) at Rosport/ Ralingen, Tier, April 25, 1950; Art. 8, Agreement between Botswana, Lesotho, Nambia and 
States to have the option of submitting to arbitration or adjudication without making it compulsory. For instance, the 1955 Lake Lugano Convention provides that 'any dispute concerning the interpretation or application of this Convention, which cannot be settled by negotiation, may be submitted, at the request of either Government, to the International Court of Justice' ${ }^{89}$

Such diversity in approaches to dispute settlement within watercourse treaties meant that the ILC had a difficult task in finding an approach that would be agreeable to all States. Middle ground was reached by making the third-party fact-finding commission compulsory, but leaving discretion for States to decide, albeit in good faith, whether or not to take up the recommendations of the commission. As with the other areas of the Convention that have been discussed within this section, it was clear that the fragmented and diverse nature of watercourse treaties posed a challenge for the ILC in agreeing on rules and principles that might be acceptable to all. In several incidences, this meant that the ILC had to draw upon other sources or consider how further detail might help clarify the more general provisions found within treaty practice. In relation to scope, the ILC focused on more recent treaty arrangements and non-binding instruments, which reflected advances in scientific understanding of watercourse systems. In the case of substantive norms, the ILC made a significant contribution by clarifying the relationship between equitable and reasonable utilisation and no significant harm. The same can be said for the rules on notification and consultation. Rules on notification and consultation are amongst the most critical procedures relating to international watercourses, as they provide a trigger by which States can then ascertain whether a particular planned use is equitable and reasonable. By drawing upon and developing the more general provisions found in watercourse treaties, the ILC helped to advance detailed procedural rules of notification and consultation. A key contribution of the ILC was therefore to clarify and add detail to the fragmented system of watercourse treaties. The extent to which that exercise strengthened the law relating to international watercourses will be considered in the conclusion.

\section{CONCLUSION - FROM WATERCOURSE TREATIES TO THE UN WATERCOURSES CONVENTION, AND BACK AGAIN?}

In the North Sea Continental Shelf Cases the ICJ observed that if a widespread and representative number of States agree to be bound by a treaty and apply the provisions of the treaty in their practice, the rules originally found in the treaty may, sometimes in a short period of time, come to reflect customary international law and thus indirectly bind the States not party to that treaty. ${ }^{90}$ Taken further, it has been argued that a

South Africa for the Establishment of the Orange-Senqu River Commission, Windhoek, November 3, 2000.

89 Art. 11, Convention between Italy and Switzerland Concerning the Regulation of Lake Lugano, Lugano, September 17, 1955. See also Art. 60, Statute of the River Uruguay, supra note 75 .

90 North Sea Continental Shelf cases (Ger. v. Neth., Den.) Judgment, 1969 ICJ Rep. 3, II77 (February 20). 
collection of bilateral treaties regulating similar conduct might, if widespread and representative, reflect customary international law. ${ }^{91}$ It would be difficult to argue that the number and reach of watercourse treaties at the time of adopting the Watercourses Convention was widespread and representative. As noted earlier, many transboundary watercourses lacked any treaty arrangements, and even where treaties had been adopted they perhaps did not cover all the aspects that were covered by the Watercourses Convention, or only some of the States within a watercourse were party to them. Additionally, existing watercourse treaties tend to be quite diverse in their content.

As noted above, it was the fragmented nature of watercourse treaties that led to the UN General Assembly recommending the ILC take up the study of the law of the non-navigational uses of international watercourses in the first place, and for the General Assembly to conclude a framework convention on the topic. ${ }^{92}$ Any expectation that watercourse treaties would be the main source of evidence of State practice and opinion juris in the drafting of the UN Watercourses Convention was therefore realistically low at the outset of the work. Faced with this challenge, the ILC had to rely upon additional evidence of State practice and opinio juris within diplomatic correspondence and official papers; outputs of intergovernmental organisations, meetings and conferences; reports and studies of intergovernmental and international non-governmental organisations; studies of individual experts; and decisions of international courts and tribunals in order to codify and progressively develop customary international law in this field. No doubt, the process by which States commented on drafts put forward by the ILC, and negotiated the text of the Convention in the UN General Assembly Sixth Committee, also went a long way to fostering consensus amongst watercourse States on the key rules and principles relating to international watercourses. $^{93}$

As an effort in the codification and progressive development of customary international law the work of the ILC was seen as a success - most notably by the ICJ in the Gabčíkovo-Nagymaros case just four months following the Convention's adoption. ${ }^{94}$ What then has been its influence on watercourse treaties? Practice since the adoption of the Convention demonstrates that it has had some notable successes in influencing practice. Faced with challenges in implementing the 1995 Southern African Development Community (SADC) Protocol on Shared Watercourse Systems, ${ }^{95}$ Southern African States decided to adopt a Revised Protocol on Shared Watercourses in

91 R Baxter, Treaties and Custom, in COllected Courts of THE Hague ACAdemy OF INTERNATIONAL LAW 75-91 (Brill 1970).

92 Draft Articles on the Law of the Non-navigational Uses of International Watercourses, February 17, 1995, U.N. G.A. Res. 49/52.

93 Esther Schroeder-Wildberg, The 1997 International Watercourses Convention - Background and negotiations, TU Berlin Working Paper, 2002, https://www.landschaftsoekonomie.tuberlin.de/fileadmin/a0731/uploads/publikationen/workingpapers/wp00402.pdf.

94 Gabčíkovo-Nagymaros Case, supra note 41, at 56. See also, Stephen C. McCaffrey, The Contribution of the UN Convention on the Law of the Non-navigational Uses of International Watercourses, 1 INTERNATIONAL JOURNAL OF GLOBAL ENVIRONMENTAL ISSUES 250 (2001).

95 Protocol on Shared Watercourse Systems in the SADC Region, Johannesburg, August 28, 1995. 


\section{Research handbook on international water law}

March 2000.96 Much of the content of the Revised Protocol reflects key provisions of the UN Watercourses Convention. ${ }^{97}$ The SADC experience can therefore be seen as an example of how adoption of the UN Watercourses Convention has triggered the negotiation of strong watercourse treaty arrangements at a regional level.

While the story is ongoing, it has also been suggested that the Watercourses Convention has been influential in shaping the development of cooperative arrangements on the Nile. Brunée and Toope, for instance, maintain that the work of the ILC and General Assembly leading to the adoption of the Watercourses Convention helped to bring diverging opinions of upstream and downstream Nile basin States closer together. ${ }^{98}$ Critics might point to the failure of all States to agree to the Nile Cooperative Framework and the unresolved issue of Article 14 related to water security. ${ }^{99}$ However, regardless of the final outcome, it is clear that the majority of the substantive and procedural provisions of the Nile Cooperative Framework, agreed upon by both upstream and downstream States, closely align to the provisions of the Watercourses Convention. Additionally, the Declaration of Principles on the Grand Ethiopian Renaissance Dam, signed by the heads of States of Egypt, Ethiopia and Sudan in 2015, might be seen as in part influenced by the Watercourses Convention, particularly in relation to the substantive norms of equitable and reasonable utilisation and no significant harm. ${ }^{100}$ More broadly, the Nile example illustrates the close interplay between the Watercourses Convention and watercourse treaties.

A further example of where the Watercourses Convention has influenced watercourse treaties can be seen in the case of the Mekong. Vietnam became the 35th party to the Watercourses Convention, and in so doing triggered the Convention's entry into force. ${ }^{101}$ A major motivation for Vietnam joining the Convention, was in order to supplement the provisions of the Mekong Agreement. ${ }^{102}$ In particular, Vietnam felt that the provisions contained in the Watercourses Convention related to notification and consultation could provide a useful complement to the more general arrangements contained within the Mekong Agreement and its supplementary procedures and guidelines. ${ }^{103}$

96 Revised Protocol on Shared Watercourses in the SADC, Windhoek, August 7, 2000.

97 Daniel Malzbender \& Anton Earle, Southern Africa, in THE UN WATERCOURSES CONVENTION IN FORCE - STRENGTHENING INTERNATIONAL LAW FOR TRANSBOUNDARY WATER MANAGEMENT, supra note 28.

98 Jutta Brunnée \& Stephen J Toope, The Changing Nile Basin Regime: Does Law Matter?, 43(1) HARVARD InTERnATIONAL LAW JOURNAL 105 (2002).

99 Dereje Z. Mekonen, The Nile Basin Cooperative Framework Agreement Negotiations and the Adoption of a 'Water Security' Paradigm: Flight into Obscurity or a Logical Cul-de-sac?, 21(2) EUROPEAN JOURNAL OF INTERNATIONAL LAW 421 (2010).

100 See, http://hornaffairs.com/en/2015/03/25/egypt-ethiopia-sudan-agreement-on-declarationof-principles-full-text/. Salman A. Salman, The Grand Ethiopian Renaissance Dam: the road to the declaration of principles and the Khartoum document, 41(4) WATER INTERNATIONAL 512 (2016).

101 UN Treaty Collection, Status of Treaties, https://treaties.un.org/Pages/ViewDetails.aspx? src=IND\&mtdsg_no=XXVII-12\&chapter=27\&lang=en.

102 Bearden et al, supra note 29.

103 Id. 
While there are therefore some notable examples of where the Watercourses Convention has played a role in influencing watercourse treaties, much work remains. As noted previously, despite growing pressures on international watercourses, many watercourses still lack adequate arrangements to ensure that they are governed in an equitable and sustainable manner. Hopefully, the interplay between the Watercourses Convention and watercourses treaties will therefore intensify in the years to come. 